\title{
An Analysis of the Appearance Management Behavior of Generation MZ in the Post-Corona Era
}

\author{
Je-Sung Lee ${ }^{1}$, Boram Jun ${ }^{2}$, Byeo-Ree Kim² ${ }^{2}$ June-Young Lee ${ }^{3 *}$ \\ ${ }^{1}$ Department of Consumer Science, Sangmyung University, Seoul, Korea \\ ${ }^{2}$ Global R\&l, Cosmax, Seongnam-si, Gyeonggi-do, Korea \\ ${ }^{3}$ Department of Economics and Finance, Sangmyung University, Seoul, Korea
}

\author{
*Corresponding author: June-Young Lee, \\ Department of Economics and Finance, \\ Sangmyung University, 20 Hongjimun 2-gil, \\ Jongno-gu, Seoul 03016, Korea \\ Tel.: +82 27817534 \\ Fax: +82 222870103 \\ Email: jylee@smu.ac.kr
}

Received August 26, 2021

Revised October 23, 2021

Accepted November 29, 2021

Published December 30, 2021

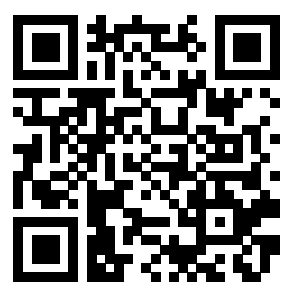

\begin{abstract}
Purpose: This study focused on generation MZ and the changes in their appearance management behavior following the outbreak of COVID-19. The purpose of this study was to design a paradigm model for the beauty behavior of Generation MZ after the spread of COVID-19. Methods: In-depth interviews among qualitative research techniques were used to examine the changes in the in-depth behavior and psychology of Generation MZ following the outbreak of COVID-19. Results: Generation MZ consumes cosmetics and set appearance management behaviorsalong with the use of cosmetics as beauty routines-to solve beauty concerns caused by situational factors (such as COVID-19), thereby expressing an individual's ideal appearance. Following COVID-19, Generation MZ had a variety of beauty concerns that differed from those prior to the outbreak. To solve these concerns, Generation $\mathrm{MZ}$ made changes, such as focusing on skincare and simplifying beauty routines. Following the conclusion of COVID-19, Generation MZ is planning appropriate levels of appearance management behavior, in consideration of the pre- and postCOVID-19 era. Conclusion: The appearance management behavior of Generation MZ has changed significantly since the COVID-19 outbreak. Detailed behavioral psychology has transformed as new beauty concerns have arisen following the spread of the virus. Therefore, it is necessary to plan a new cosmetics development and marketing strategy to satisfy the needs of Generation MZ during the pandemic.
\end{abstract}

Keywords: Generation MZ, Appearance Management Behavior, Post-Corona, Consumer Behavior, Consumer Psychology

\section{Introduction}

코로나19 바이러스의 확산으로 인해 화장품 산업을 포함한 여러 산업의 판도가 많이 바뀌고 있다. 방역을 위한 수단으로서 일상생활 에서 마스크 착용이 일반화되면서 소비자의 화장품 소비 양상이 크게 달라지고 있다. 코로나19 확산 후 기초, 색조 화장품의 구매와 활용 을 포함한 소비자 행태가 크게 달라졌으며(Park \& Kim, 2021), 화장 품 유통 채널이나 업계 마케팅 활동이 온라인 플랫폼에 기반한 비대 면 중심으로 이루어지는 등 많은 변화가 나타나고 있다(Jun \& Kim, 2020). 이처럼 코로나 19 바이러스는 소비자의 외모관리행동의 뷰티 행동을 포함한 다양한 영역에 커다란 변화를 불러일으켜, 이에 대한 면밀한 분석이 필요하다.
소비자의 뷰티에 대한 심리와 행동 역시 코로나 19확산 이후 상당 부분 변화했다. 대표적으로 전염병 확산 방지를 위해 정부는 사회적 거리 두기를 실시하면서, 소비자의 외부 활동의 정도는 급감했다. 따 라서 외부인들과 접촉이 줄어들면서 점차 화장의 필요성에 대한 인식 이 감소하면서(Park \& Kim, 2021), 전반적인 화장품 소비가 줄어들 었다.

또한 소비자들이 화장품을 소비하는 기준과 방법에 대해서도 새로 운 모습들이 나타나고 있다. 코로나19 확산에 따라 화장품 성분에 대 한 정보 탐색 정도가 증가하였으며, 특히 유해성분이 배제된 뷰티 제 품(천연, 비건 화장품 등)에 대한 관심이 크게 증가하였다. 화장품 소 비는 온라인 중심의 비대면 소비에 따른 온라인 구매가 크게 확산됨 에 따라 SNS, 뷰티 제품 리뷰 및 추천 서비스 등의 플랫폼을 활용한 
화장품 정보 공유도 더 많아질 것으로 예측된다(Park, 2020). 이와 같이 코로나19 바이러스라는 강력한 트리거 포인트(trigger point)로 인해 사회와 개인의 삶에 소비를 포함한 다양한 영역에 변화가 나타 나고 있다.

본 연구는 코로나19 바이러스라는 커다란 영향 요인으로 인한 소비 자의 심리와 뷰티 행동 변화를 이해하기 위해 하나의 소비자 '개인' 에 집중하고자 한다. 소비자 행동은 기저에 있는 소비자의 태도나 가치 관 등 심리적인 변인들을 통해 이해할 수 있다(Hong \& Park, 2005). 특 히 소비자 행동은 과거, 현재를 지나 미래로 이어지는 구조를 지니며, 과거를 토대로 현재의 소비 경험이 결정되고, 과거와 현재의 경험이 소 비자의 미래 뷰티 행동과 연관된 소망으로 이어질 수 있다(Koo \& Rha, 2015). 이와 같은 맥락에서 소비자의 뷰티 행동을 미시적인 개인의 변 화로부터 시작하여 전반적인 뷰티 트렌드의 구조적 변화로서 체계적인 접근을 통해 해석하고자 한다.

따라서 본 연구는 단순한 전염병 확산 전후를 기점으로 뷰티 행동의 변화의 이만을 살펴보는 것이 아니라, 코로나 19 바이러스가 확산된 포 스트 코로나 상황에서 변화한 소비자의 행동을 맥락적인 패러다임을 통 해 살펴보는 것에 목적을 둔다. 따라서 질적 연구방법 중 심층 인터뷰 를 활용하여 소비자의 심리와 행동을 심도 깊게 살펴보고, 도출된 자료 를 기반으로 코로나19 확산 이후 변화한 뷰티 행동에 대한 패러다임 모 형을 설계하고, 세부적인 각 단계에 따른 뷰티 행동에 대해 분석하려 한 다.

본 연구의 대상은 MZ세대에 한정하여 코로나 상황에서의 뷰티 행동 변화에 대해 집중하고자 한다. MZ세대는 1981-1995년에 출생한 M세 대(밀레니얼 세대)와 1996-2012년에 출생한 Z세대를 통칭한다. 대한 민국 $\mathrm{MZ}$ 세대는 약 1700 만 명으로 전체 인구의 $34 \%$ 를 차지하는 커다란 비중을 지니며, 타 세대와는 차별적인 생활방식 및 소비문화를 보인다. 특히 디지털 및 모바일 환경에 익숙하고 트렌드 변화에 민감해 유행을 주도할 수 있다는 특성이 있으며(Lee \& Kim, 2021), M세대는 상당한
경제력을 지니고, Z세대는 트렌드 선도력을 지닌 세대로서 변화에 민감 한 뷰티 시장에서 큰 영향력을 발휘하는 핵심 소비계층으로서 연구 대 상으로 선정하였다.

이와 같은 연구를 통해 코로나 상황으로 인한 소비자들의 뷰티 행동 변화에 대해 심도 깊게 살펴봄으로써, 향후 관련 연구의 기초자료로서 활용될 수 있을 것으로 판단된다. 또한 이를 토대로 향후 화장품 제조 및 판매업체 등 뷰티 관련 업계에서는 적절한 대응 전략 수립이 가능하 다는 점에서 시사점을 지닌다.

\section{Methods}

\section{1. 연구방법}

$\mathrm{MZ}$ 세대의 포스트 코로나 시대의 외모관리행동에 대한 소비자 심리 와 행동에 대해 심층적으로 살펴보기 위해 정성연구방법을 적용하였 다. 정성연구방법 중 선별된 사람들과의 심층적인 대화를 통해 개인의 소비생활이나 습관, 소비 스타일 등에 대한 소비자의 심리와 행동 이면 에 대한 깊은 통찰력을 도출 가능한 심층 인터뷰(In-depth Interview) 를 활용하였다(Yeo et al., 2012). 세부적으로 인터뷰가 진행되기 전 최 소한의 질문 구조를 구성하여 이루어지는 반 구조화 인터뷰(SemiStructured Interview)를 통해 연구를 진행하였다. 따라서 인터뷰 이전 에 MZ소비자의 코로나19 이전-이후의 뷰티 행동에 관한 질문을 포함 하여, 개인의 뷰티 소비에 대한 전반적인 질문을 준비하였으며 이와 함 께 상황에 따라 유기적인 질문을 계속해서 더해가는 방식으로 진행하였 다.

\section{2. 연구대상}

본 연구는 향후 뷰티 소비 시장에서 중심이 될 것이라 예상되는 $\mathrm{MZ}$ 세대를 대상으로 진행되었다. 세부적으로 외모관리행동에 대한 관여도

Table 1. Characteristics of research subjects

\begin{tabular}{|c|c|c|c|c|c|}
\hline \multicolumn{3}{|c|}{ M Generation } & \multicolumn{3}{|c|}{ Z Generation } \\
\hline Division & Age & Job & Division & Age & Job \\
\hline A & 31 & Office worker & $\mathrm{K}$ & 22 & University student \\
\hline B & 31 & Office worker & $\mathrm{L}$ & 23 & University student \\
\hline C & 27 & University Student & M & 23 & University student \\
\hline D & 27 & University Student & $\mathrm{N}$ & 23 & University student \\
\hline$E$ & 29 & Undergraduate Student & 0 & 22 & University student \\
\hline $\mathrm{F}$ & 29 & Researcher & $\mathrm{P}$ & 23 & University student \\
\hline G & 30 & Public officer & $\mathrm{Q}$ & 23 & University student \\
\hline $\mathrm{H}$ & 26 & Nutritionist & $\mathrm{R}$ & 24 & University student \\
\hline I & 29 & Office worker & $\mathrm{S}$ & 25 & University student \\
\hline J & 30 & Office worker & $T$ & 23 & University sftudent \\
\hline
\end{tabular}

* Generation M and Generation Z are classified according to the year of birth. It refers to households born in 1981-1995 and 1996-2012. 
가 높은 여성 소비자로 한정하여 전국에 거주하고 있는 밀레니얼 세대 (M세대), Z세대 각 10 명을 모집하여 총 20 명을 연구대상으로 실증연구 를 진행하였다. 연구대상이 특정한 군집을 나타내지 않기 위해 다양한 직업과 개인적 특성을 지니도록 하였다. $\mathrm{M}$ 세대는 영양사, 연구원, 사 무직, 대학원생, 취업 준비생 등과 같은 다양한 직업군이 포함될 수 있 도록 표집하였으며, Z세대는 스스로 소비를 결정하는 대학생 이상의 소 비자로 구성하였다. 이상의 연구대상은 아래 Table 1과 같으며, 2020년 11 월 13 일부터 12 월 30 일 간 인터뷰를 통한 자료 수집이 이루어졌다.

\section{3. 연구 진행 및 분석}

심층 인터뷰를 통해 수집된 자료는 총 5 단계의 진행 및 분석 과정을 거쳤다. 우선적으로 실증 인터뷰가 이루어지기 전에 연구 대상자에게 본 연구에 대한 참여 동의와 연구에 필요한 자료를 사전에 요구하였으 며(1단계), 선정된 연구 대상자를 대상으로 2-3명의 그룹으로 만들어 FGI 형식으로 인터뷰를 진행하였다(2단계)(Sun, 2014). 진행된 인터뷰 자료를 기반으로 하여, 약 2 일 내에 분석을 위한 스크립트를 전사하였 으며(3단계), 작성된 스크립트를 단어, 문장, 구, 문단 등으로 구분하여 분석을 진행하였다(4단계). 최종적으로 앞서 진행된 실증 연구의 분석 을 통해 전 연구자가 모여 자료 검토 및 시사점 도출 과정을 거쳤다(5단 계).

\section{Results and Discussion}

\section{MZ세대의 외모관리행동 패러다임}

본 연구에서 심층 인터뷰를 통해 $\mathrm{MZ}$ 세대의 외모관리행동에 대한 패 러다임 모형을 Figure 1과 같이 도출하였다. 뷰티 행동 패러다임은 총 5 가지 세부적인 과정으로 구성되어 있다. $\mathrm{MZ}$ 세대의 외모관리행동은 그 들이 가지고 있는 '뷰티 고민'에서부터 시작하여 이를 해결하기 위한 '소 비 행동'으로 이어진다. 소비가 이루어질 때는 현 시대의 다양한 트렌드 현상과 Covid-19와 같은 특수적인 '상황적 요인'에 대한 영향을 받게 된다. 소비 행동에서 자신만의 취향과 라이프스타일에 적합한 화장품은 $\mathrm{MZ}$ 세대의 '뷰티 루틴'이 되며, 이와 같은 과정을 통해 궁극적으로 그들 이 원하는 이상적인 '나'를 만드는 일련의 뷰티 과정으로 마무리된다.

외모관리 행동, 그 중 화장행동의 맥락을 밝히고자 한 선행 연구의 경우, 동일한 소비자가 상황에 따라 화장품의 구매행동 및 사용행동을 포괄하는 화장행동 전반이 달라짐을 밝힌 바 있다(Koo \& Rha, 2015). 소비자의 상품 사용이 과거, 현재를 지나 미래로 이어지는 구조를 지니 며, 과거의 경험이 현재의 행동에 영향을 미친다는 것을 전제하고 화장 행동의 맥락을 밝히고자 한 목적은 본 연구와 동일하다. 나아가 본 연구 가 선행 연구와 다른 점은 소비자들의 외모관리행동이 상황적인 요인 뿐 아니라, 뷰티 고민이라는 문제의식에서부터 기인함을 밝히는 데 있 다.

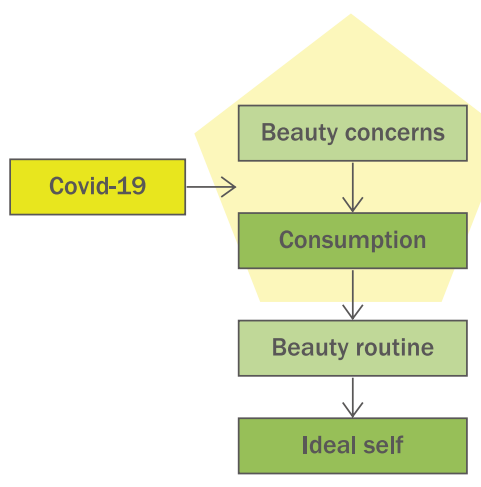

Figure 1. Beauty behavior paradigm of $\mathrm{MZ}$ generation.

\section{2. 외모관리행동 패러다임 모형 세부 과정}

심층 인터뷰를 통해 도출한 Figure 1의 MZ세대의 외모관리행동 패러다임 모형의 5 가지 과정(뷰티 고민, 상황적 요인(코로나19), 소 비 행동, 뷰티 루틴, 이상적 이미지)에 대한 세부적인 내용은 다음과 같다.

\section{1) 뷰티 고민}

소비자들의 외모관리행동이 나타나기 위해서는 자신이 갖고 있는 뷰티, 즉 아름다움에 대한 고민에서부터 시작된다. 심층 인터뷰를 통 해 확인한 $\mathrm{MZ}$ 세대의 피부 고민은 아래 Table 2 와 같다. MZ세대는 공통적으로 '건조, 트러블, 잡티, 유·수분 밸런스, 수분 부족 지성 피 부(수부지)'라는 뷰티 고민을 지니고 있는 것으로 나타났다. 이와 더 불어 M세대는 Z세대와 다르게 '모공, 생기, 주름, 각질, 피지, 다크서 클'과 같은 세부적인 뷰티 고민을 추가적으로 언급하였다. 이를 통해 상대적으로 연령이 낮은 Z세대에 비교하여 $\mathrm{M}$ 세대가 보다 구체적인 뷰티 고민을 지니고 있는데, 이는 코로나 19 바이러스의 확산에 따라 오랜 시간 마스크 사용을 해야 함에도 밀레니얼 세대는 직장 생활 내 에서 화장 행동을 지속적으로 하게 되면서 생겨나는 피부 트러블이나 유·수분 밸런스, 모공, 각질 등의 뷰티 문제가 심화된 것으로 분석되 었다.

\section{2) 상황적 요인(Covid-19)}

2019년에 발생한 예상치 못한 코로나19 바이러스로 인해 소비자 의 삶은 뷰티를 포함한 다양한 부분에서 변화가 나타났다. 코로나 19 바이러스는 $\mathrm{MZ}$ 소비자의 외모관리행동 즉, 화장품 소비와 실제적인 행동의 변화에도 큰 영향을 미쳤다. 심층 인터뷰를 통해 확인한 $\mathrm{MZ}$ 세대의 코로나19에 대한 뷰티 행동과 감정적 변화는 아래 Table 3 과 같이 나타났다. 이를 통해 포스트 코로나 시대 새롭게 나타나고 있는 뷰티 트렌드들을 확인할 수 있다.

첫째, $\mathrm{MZ}$ 소비자들의 피부 자체에 대한 근원적인 관심이 증대하 
고 있다. 바이러스 확산을 방지하기 위해 소비자들은 이전과 다르게 생활 속에서 마스크를 착용하게 되었다. 뿐만 아니라 정부의 사회적 거리두기 정책 실행으로 인해 MZ세대를 포함한 많은 소비자들이 외 출을 제한하면서 자연스럽게 메이크업에 대한 관심이 줄어들었는데, 이는 코로나 19 발생 이전과 이후의 화장에 대한 관심도가 더 낮음을 밝힌 선행 연구와 맥락을 같이 한다(Park \& Kim, 2021). 이와는 반 대로 스킨케어에 대한 전반적인 관심은 증가하였다. 예를 들어 $\mathrm{MZ}$ 세 대는 공통적으로 포스트 코로나 상황에서 심화된 트러블에 신경을 쓰 며, $\mathrm{M}$ 세대는 이와 함께 모공, 탄력, 팔자주름 등 구체적인 뷰티 고민 을 해결하고자 관련 기능을 소구하는 화장품을 사용하였다. 반면 색 조 화장품에 대한 소비나 관심은 현저히 줄어들었는데, 메이크업 효 과를 낼 수 있는 톤업 선크림이나, 마스크 사용시 묻어나지 않는 파 운데이션과 같은 화장품에 대한 추구가 나타났다.

둘째, 외모관리행동에 관심이 많은 MZ세대에서 뷰티 행동의 간소 화가 이루어졌다. 코로나 19 로 인해 외부활동이 적어지면서 마스크로 가려지는 부위는 메이크업 제품을 바르지 않고, 수정화장을 생략하 는 등 전체적으로 뷰티 루틴을 간소화하거나, 대면 활동이 있을 때에 만 선택적으로 화장하게 되었다.

셋째, 마스크로 인한 트러블 등 뷰티 고민이 생겼던 MZ세대는 이 를 해결하기 위한 뷰티 행동을 하며, 일정 시간이 지난 후에는 결과 적으로 긍정적인 피부 변화가 나타났다고 응답하였다. 코로나 19 발 발 이후 $\mathrm{M}$ 세대와 $\mathrm{Z}$ 세대 모두 피부 자체에 대한 근원적인 관심 증대 및 뷰티 루틴 간소화로 인해 피부 결 개선, 편안함 등 피부가 좋아짐 을 체감하였다고 언급하였다. 외적인 미용적 혜택뿐 아니라 의무감 에 기반하는 뷰티 행동에서 벗어나 선택적으로 화장한다는 자유로움 과 같은 심리적 혜택도 나타났다. 이에 따라 MZ세대는 코로나 19 종 식 이후 외모관리행동에 대해 코로나 발생 이후보다는 촉촉한 피부표 현, 립 메이크업 등 코로나 상황에서 하지 못했던 다채로운 뷰티 행 동을 계획하지만, 전염병 발생 이전보다는 간결한 뷰티 행동을 계획 하는 것으로 분석되었다.

\section{3) 소비 행동}

소비자들은 뷰티 고민을 해결하기 위해 자신을 둘러싼 상황적 요 인을 고려하여, 자신에게 맞는 뷰티 제품을 구매한다. 심층 인터뷰를 통해 확인한 MZ세대의 소비 기준은 아래 Table 4 와 같다. 선행연구 에서 인구통계적, 사회경제적 특성에 따라 라이프스타일을 유형화할 수 있으며, 각 라이프스타일에 따라 제품 구매행동에 차이가 있음을 밝힌 것과 같이 본 연구에서도 $\mathrm{M}$ 세대와 $\mathrm{Z}$ 세대의 소비 행동에 공통점 과 함께 일부 차이점도 나타났다(Hong \& Park, 2005).

화장품 구매결정요인과 관련된 선행연구에서는 품질, 디자인, 가 격, 브랜드, 사용정보 총 5 개 요인을 추출하였다(Oh, 2020b). 본 연 구에서는 FGI에서 추가로 언급된 내용을 포괄적으로 분석하기 위하 여, 구매결정요인을 다음과 같이 변용하였다. 품질 항목은 기능을 중 점적으로 하고, 안전성 및 성분, 사용감 및 제형, 향 3 개 항목을 추가 로 포함시켰으며, 마지막으로 사용정보는 제품에 대한 사용후기 외 마케팅, 홍보 방식까지 포함시켜 총 8개 항목으로 구분하였다.

세부 내용을 살펴보면 MZ세대는 공통적으로 이들은 순한 성분의 실질적인 효과를 지닌 심플하면서도 집중적으로 뷰티 고민을 해소할 수 있는 제품을 선호한다. 세부적으로는 $\mathrm{M}$ 세대는 $\mathrm{Z}$ 세대에 비해 유해 성분 포함여부, 인체적용 임상시험 진행여부 등 안전성이나 결과적 으로 나타날 수 있는 효능과 같이 실질적인 요인에 대해 신경을 많이 쓴다.

또한 $\mathrm{M}$ 세대는 친환경적인 이슈나 기업의 사회적 책임을 포함한 윤리적 경영, 브랜드 철학에 대해 관심을 많이 두는 것으로 나타났 다. 반면 Z세대는 $\mathrm{M}$ 세대에 비해 성분 탐색 정보가 적게 나타나며, 보 다 감각적인 광고 슬로건이나 인플루언서를 포함한 유명인 등과 같은 감성적 요인에 영향을 많이 받아 보다 다채롭고 새로운 뷰티 행동을 시도해보는 것으로 도출됐다.

선행 연구에 따르면, 화장품 기업의 친환경 활동 수준이 높거나, 소비자들의 지각된 이미지가 '고급스러운' 또는 '안전한' 경우에 소비 자의 구매 동기에 긍정적인 영향을 미친다. Oh (2020a) 본 연구 결과

Table 2. Beauty concerns of generation MZ

\begin{tabular}{lcc}
\hline \multirow{2}{*}{ Mentioned contents } & \multicolumn{2}{c}{ Number of mention } \\
\cline { 2 - 3 } Dry skin & M Generation & Z Generation \\
Balance of oil and moisture (Complex skin) & 5 & 1 \\
Atopy (Sensitive skin) & 4 & 1 \\
Acne, skin trouble (Oily skin) & 3 & - \\
Blemishes, freckles & 2 & 3 \\
Pores & 2 & 2 \\
Wrinkles & 2 & 1 \\
Dead skin cells & 2 & - \\
Dark circles, complexion & 3 & - \\
No skin concerns & 1 & - \\
\hline
\end{tabular}




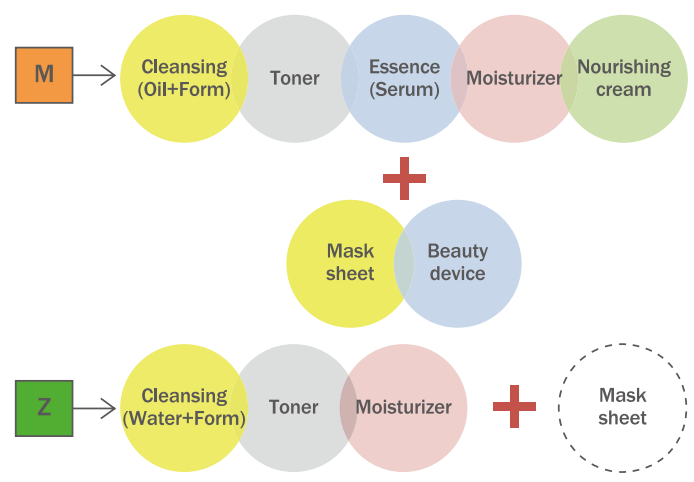

Figure 2. Beauty routine of $M Z$ generation.

는 이를 부분적으로 실증하면서 동시에 그 세부 내용을 밝히고 있어, 소비자의 구매 동기를 진작시키는 전략 수립에 도움을 줄 수 있다는 데 시사점이 있다.
용기, 디자인에 있어서는 $\mathrm{M}$ 세대는 기본적인 디자인 보다는 용기 디자인에 관심을 두며, 무게감이 있는 용기는 제품에 대한 신뢰감을 갖게 된다고 언급하였다. 반면 Z세대는 눈에 띄는 제품의 디자인에 관심을 두는 것과 같이 외형적인 제품에 대한 관심도가 높게 나타났 다.

$\mathrm{MZ}$ 세대는 제품을 제품에 대한 정보를 찾아보는 채널 및 구매 채널 은 아래 Table 5 와 같으며, MZ세대 간 차이가 없는 것으로 분석되었 다. MZ세대 모두 충성도 및 신뢰 기반으로 제품을 재구매 시 온라인 을 활용하나, 경험이 필요한 색조 화장품이나 새로운 뷰티 제품을 구 매 시에는 오프라인 소비를 하는 것으로 나타났다. 또한 최근 주요한 정보 채널이 되고 있는 유튜브(브이로그/뷰티방송)이나 블로그 위주 의 정보 탐색 정도가 높게 나타나며, $\mathrm{Z}$ 세대는 $\mathrm{M}$ 세대에 비해 친구와 같은 또래집단의 영향 정도가 높은 것으로 나타났다.

4) 뷰티 루틴

$\mathrm{MZ}$ 소비자는 포스트 코로나 상황에서 생겨난 뷰티 고민을 해결하 기 위해 화장품 소비를 하며, 궁극적으로 자신들의 니즈를 충족할 때

Table 3. Changes in the beauty behavior of generation MZ (caused by COVID-19)

\begin{tabular}{|c|c|c|}
\hline \multirow{2}{*}{ Classification } & \multicolumn{2}{|c|}{ Number of mention } \\
\hline & M Generation & Z Generation \\
\hline \multirow{9}{*}{$\begin{array}{l}\text { Changes before and after COVID-19 } \\
\text {-Beauty behavior }\end{array}$} & $\begin{array}{l}\text { I do not wear makeup because I am wearing a } \\
\text { mask. }\end{array}$ & $\begin{array}{l}\text { Instead of foundation, I only put on sunscreen that } \\
\text { has tone up function. }\end{array}$ \\
\hline & I focus on eye makeup. & I do not fix my makeup. \\
\hline & I buy less lipstick. & I do not put on blush. \\
\hline & I buy more skincare products than makeup. & $\begin{array}{l}\text { By increasing skincare, I changed the composition } \\
\text { of my consumption to cosmetics. }\end{array}$ \\
\hline & $\begin{array}{l}\text { I increased the number of times I put on facial } \\
\text { masks. }\end{array}$ & I use a lighter texture. \\
\hline & There's no change. & There's no change. \\
\hline & I apply it the same way as before. & \\
\hline & $\begin{array}{l}\text { If makeup gets erased because of the mask, I put } \\
\text { it on top of that. }\end{array}$ & $\begin{array}{l}\text { I think I apply more products considering that it } \\
\text { is going to erase it off. }\end{array}$ \\
\hline & I ended up using a lot of fixers. & \\
\hline \multirow{4}{*}{$\begin{array}{l}\text { Changes before and after COVID-19 } \\
\text {-Skin condition }\end{array}$} & I have a lot of skin trouble on my cheeks and chin. & $\begin{array}{l}\text { I have lot of skin trouble because I put on makeup } \\
\text { even if I wear a mask. }\end{array}$ \\
\hline & $\begin{array}{l}\text { I think my skin got better because I did not put on } \\
\text { makeup. }\end{array}$ & $\begin{array}{l}\text { My skin definitely got better because I did not put } \\
\text { on much makeup. }\end{array}$ \\
\hline & I think my skin got more comfortable. & \\
\hline & I think I am used to the mask now. & There's no change in my skin. \\
\hline \multirow{5}{*}{$\begin{array}{l}\text { Changes before and after COVID-19 } \\
\text {-Emotions }\end{array}$} & It is comfortable. & I feel free. \\
\hline & It saves my time. & \\
\hline & & I am sad that I like putting on makeup. \\
\hline & & I feel bored. \\
\hline & & I think I got lazy and I feel uncomfortable. \\
\hline \multirow{2}{*}{$\begin{array}{l}\text { Changes after the end of COVID-19 } \\
\text { (expected) }\end{array}$} & $\begin{array}{l}\text { I think it will be more than now, but less than } \\
\text { before. }\end{array}$ & I think I am going to buy more blushers and lipstick. \\
\hline & I think I will find a way to put on light makeup. & I think a variety of new products will come out. \\
\hline
\end{tabular}


비로소 뷰티 루틴으로 받아들인다. 심층 인터뷰를 통해 확인한 $\mathrm{MZ}$ 세대의 뷰티 행동 루틴은 Figure 2와 같다. 뷰티 고민이 상대적으로 적은 것으로 분석되었던 $\mathrm{Z}$ 세대는 $\mathrm{M}$ 세대에 비해 보다 간소화된 뷰티 루틴을 가지는 것으로 도출되었다. 이상으로 포스트 코로나 상황 속 $\mathrm{MZ}$ 세대의 뷰티 루틴에 대한 세부적인 내용은 다음과 같다.

직장인의 비율이 높고, 코로나 19 바이러스로 마스크 사용이 증가 하면서 이로 인한 피부 트러블이 많이 발생한 $\mathrm{M}$ 세대에서는 Z세대에 비해 보다 복합적인 뷰티 루틴이 형성되었다. 화장 행동의 빈도가 높 았던 $\mathrm{M}$ 세대는 보습감을 위해 클렌징 오일과 클렌징 폼의 2차 세안을 중심으로 하고, 토너 이후 기능성 에센스와 로션과 크림(수분/영양) 의 과정으로 이어졌다. 또한 일상생활에서 마스크 시트와 뷰티 디바 이스를 주기적으로 활용하는 것으로 나타났다.
반면 $\mathrm{Z}$ 세대는 코로나 상황에서 3 가지의 핵심적인 뷰티 루틴을 가 지는 것으로 분석되었다. 우선적으로 2 차 세안을 하는 것은 $\mathrm{M}$ 세대와 동일하였으나, 1 차 세안제로 클렌징 오일 대신 더 높은 비중으로 클 렌징 워터를 사용하며, 토너와 수분크림으로 간편하게 뷰티 루틴을 완성하였다. 수분 크림 같은 경우는 질감이 다른 종류를 구분하는 행 태가 일부 확인되었다. 상대적으로 산뜻한 느낌의 가벼운 수분크림 과 함께 보다 무거운 크림을 덧발라 보습감을 보충해주는 루틴이 도 출되기도 하였다. 또한 $\mathrm{Z}$ 세대에게 마스크 시트의 활용은 비정기적으 로 나타났는데, 친구들과의 여행, 사진 촬영과 같은 특별한 이벤트 등 특정 상황 하에서 사용하는 것으로 분석되었다.

5) 결과(이상적인 나)

Table 4. Consumption behavior of generation MZ (basis of consumption)

\begin{tabular}{|c|c|c|}
\hline \multirow{2}{*}{ Classification } & \multicolumn{2}{|c|}{ Number of mention } \\
\hline & M Generation & Z Generation \\
\hline \multirow{7}{*}{ Function } & It has to solve my skin problems. & Moisturizing \\
\hline & Moisturizing & \\
\hline & Soothing skin (Relieving skin trouble) & \\
\hline & Whitening & \\
\hline & Anti-aging & \\
\hline & 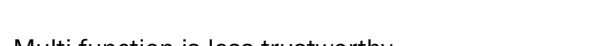 & It has to stick to the basics. \\
\hline & 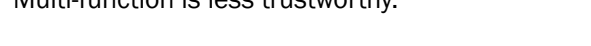 & I never use all-in-one products. \\
\hline \multirow{6}{*}{ Safety, Ingredients } & It needs to be safe. & Ingredients are important for skincare products. \\
\hline & I do not buy products with harmful ingredients. & I think It should be gentle. \\
\hline & It is important not to get skin trouble. & \\
\hline & $\begin{array}{l}\text { I look up ingredients while looking at the Hwahae } \\
\text { application. }\end{array}$ & \\
\hline & Llike noturalictic incrodionts & $\begin{array}{l}\text { There's some ingredients that I like such as } \\
\text { "Heartleaf Houttuynia." }\end{array}$ \\
\hline & t ine naturalistic ingreurents. & $\begin{array}{l}\text { I think it needs to be clean and fresh, so I look } \\
\text { at the manufacturing date. }\end{array}$ \\
\hline \multirow{6}{*}{ Brand } & Brand popularity & Brand preference \\
\hline & I do not really use new brands. & I like Derma products. \\
\hline & If products are tested on animals or not & \\
\hline & Ethical brand management policy & \\
\hline & Eco-friendly & \\
\hline & Avoid using plastic containers. & \\
\hline Price, capacity & Reasonable price compared to the capacity & I look at the price first. \\
\hline \multirow{2}{*}{ Courage, design } & Preferred container type (tube type) & Convenience \\
\hline & Courage design that gives reliability (pottery) & Simple or cute design \\
\hline Marketing, promotion & $\begin{array}{l}\text { Popularity ranking of cosmetics evaluation app } \\
\text { (Hwahae) or sales channel (Olive Young) }\end{array}$ & $\begin{array}{l}\text { Marketing phrases, slogans } \\
\text { Reviews }\end{array}$ \\
\hline Texture, sensory & Not too sticky & Moist \\
\hline Scent & Preferred scent (no scent, herb scent) & Avoid strong scent. \\
\hline
\end{tabular}


소비자들은 궁극적으로 자신이 꿈꾸는 이상적인 이미지를 위해 화 장품을 도구적으로 활용한다. 심층 인터뷰를 통해 확인한 MZ세대 의 이상적으로 생각하고 궁극적으로 추구하는 자신의 이미지에 대해 Table 6 과 같다. $\mathrm{MZ}$ 세대에게는 공통적으로 약 3 가지 형태의 이상적 인 이미지를 추구하는 것으로 분석되었다. 우선적으로 맑고 청명한 느낌을 지닌 '깨끗한 이미지'이다. 둘째, 생기 있고 피부에서 물광이 나타나는 '건강한 이미지'이다. 마지막으로 세련되고, 전문성이 느껴 지는 '도시적인 이미지'를 원하는 것으로 나타났다.

외형적으로 깨끗하고 생기 있으며, 물광이 있는 느낌을 원하는 동 시에 전문적이고, 세련된 이미지를 원하는 것은 일종의 내•외적인 아 름다움을 모두 추구하는 것이라 할 수 있다. 외적인 아름다움과 함께 당당하고 능력 있는 모습에 대한 욕망이 함께 도출되었다. 세대에 따 라 상이한 점으로는 $\mathrm{M}$ 세대는 본인이 가지고 있는 장점을 극대화하여 아름다움을 강조하고 싶어하는 반면에, Z세대는 상황과 분위기에 따 라 다양한 이미지를 표현하고자 하는 것으로 분석되었다.

\section{Conclusion}

본 연구는 화장품 시장의 중심이 되고 있는 MZ세대를 대상으로 소 비자 집단 인터뷰를 진행하여 코로나 상황에서 화장품 사용 및 외모
관리행동에 관한 심리와 행동 변화를 분석하였다. 2020년 11월 13 일 부터 연구를 시작하여 12 월 30 일까지 $\mathrm{M}$ 세대 10 명, $\mathrm{Z}$ 세대 10 명을 모 집하여 총 20 명의 인터뷰 내용을 최종 분석에 활용하였으며, 이를 통 해 도출된 주요한 연구 결과와 시사점은 다음과 같다.

첫째, 코로나19 바이러스 대유행이라는 특수한 상황에서 MZ 소비 자의 변화하는 뷰티 행동에 관한 패러다임 모형을 도출하였다. 포스 트 코로나 상황에서 MZ소비자의 뷰티 행동은 총 5 가지 단계로 구성 되어 진행된다. 우선적으로 코로나 19 라는 특수한 상황적 요인에 따 라 피부 트러블이나 유수분 밸런스 등의 뷰티 고민이 생긴다. 이런 뷰티 고민을 해결하기 위해 화장품 소비가 나타난다. 나아가 화장품 을 사용하고 그 효과에 대한 만족을 경험하면서 뷰티 루틴을 형성한 다. 궁극적으로 자신이 꿈꾸는 이상적인 이미지, 깨끗하면서도 건강 한, 세련된 이미지를 표현하고자 한다. 이러한 패러다임 모형을 통해 코로나 상황에서 $\mathrm{MZ}$ 소비자의 행동을 부분적으로 파악하는 것이 아 닌 맥락적이고 유기적으로 파악하여, 뷰티 행동을 하나의 프로세스 로 이해할 수 있었다.

둘째, 예상치 못한 코로나19 바이러스 대유행이라는 상황 아래 새 롭게 나타나는 $\mathrm{MZ}$ 세대 소비자들의 뷰티 행동에 대해 분석하였다. 코 로나19로 인해 일상에서 마스크를 항시 사용하게 되면서 피부 트러 블이나 각질 등의 뷰티 고민이 새롭게 나타나고, 화장 행동이 급격 히 감소하였다. 이에 코로나 상황 속에서 화장품 소비는 색조 화장보

Table 5. Consumption behavior of Generation MZ (purchasing \& searching information channel)

\begin{tabular}{lll}
\hline Classification & \multicolumn{1}{c}{ M Generation } & \multicolumn{1}{c}{ Number of mention } \\
\cline { 2 - 3 } & \multicolumn{1}{c}{ Offline (Drug store, department store) } \\
I buy the makeup products after seeing them. & Offline (Drug store, department store) \\
Online (Naver shopping) & Online (Naver shopping, Brand's official homepage) \\
& Repurchase of the product that has been used & $\begin{array}{l}\text { Searching for the lowest price } \\
\text { It is rarely sold out online. }\end{array}$ \\
Searching information Channel & Blogs, communities, etc. & SNS such as YouTube, Instagram, Blogs, etc. \\
& Recommendations of YouTube influencer & $\begin{array}{l}\text { Review of cosmetics evaluation application } \\
\text { (Hwahae) }\end{array}$ \\
\hline
\end{tabular}

Table 6. Generation MZ's description of their ideal self

\begin{tabular}{ll}
\hline M Generation & Z Generation \\
Clearness & Clearness \\
Neat & No blemishes \\
Organized clean & \\
Vibrant & Glossy \\
& Healthy \\
Urban & Sophisticated \\
Elegance for age & Decorating oneself well \\
\hline
\end{tabular}


다는 뷰티 고민을 해결하기 위한 기초 화장품에 집중되었다. 이러한 $\mathrm{MZ}$ 세대의 외모관리행동의 변화는 포스트 코로나 상황에서 마스크 사용 및 사회적 거리두기로 인한 외출 감소 등의 원인으로 궁극적으 로 상당부분 간소화된 것이라 할 수 있다.

이는 코로나 19 바이러스 확산 후 MZ세대가 뷰티 고민을 해소하 기 위한 하나의 해결책으로 채택한 것으로 판단된다. MZ세대는 화 장 행동의 간소화와 기초 케어 중심으로 변화한 뷰티 행동으로 인해 궁극적으로 피부 결 개선과 같은 외적인 혜택, 편안함, 화장을 하지 않아도 되는 자유로움과 같은 심리적, 내적인 혜택 등을 모두 경험 하였다. 소비자들은 이러한 긍정적인 경험에 대해 언급하며, 코로나 19 종식 이후의 뷰티 행동에 대해 코로나 19 발생 이후보다는 다양하 고, 화려하지만, 발생 이전보다는 간결하고 단순화하게 할 것이라 응 답하였다. 이를 통해 코로나 19 종식 이후 $\mathrm{MZ}$ 세대의 뷰티 행동은 $\mathrm{BC}$ (Before COVID-19)와 AC (After COVID-19) 시기의 외모관리행동 의 중간 수준, 즉 가장 적정한 정도를 나타내는 골디락스 가설에 부 합하도록 행해질 것임을 예측할 수 있다(Seo, 2020).

셋째, 패러다임 모형의 각 단계에서 MZ세대의 공통점과 차이점에 대해 세부적으로 분석하였다. $\mathrm{M}$ 세대는 직장생활을 하고 있다는 점에 서 Z세대와는 구별되는 상황적인 특성을 가지고 있다. 이로 인해 M 세대는 $Z$ 세대보다 더욱 구체적인 뷰티 고민을 지닌 것으로 나타났다. 건조나 트러블, 잡티 등과 같은 공통적인 고민 외에도 모공, 각질, 주 름 등의 다양하고 세부적인 고민을 지니고 있었다. 또한 뷰티 루틴이 간소화된 것은 $\mathrm{MZ}$ 세대의 공통적인 특성이나, 결과적으로 Z세대는 토너와 수분 크림과 같이 화장품의 기초 라인에 집중하는 행태를 보 인 반면 $\mathrm{M}$ 세대는 세럼이나 에센스, 크림(수분/영양)과 같이 기능성 을 지닌 화장품에 높은 관심을 보인 것으로 분석되었다.

이처럼 코로나 19 라는 같은 상황 하에서 MZ세대는 서로 공통적으 로 문제를 경험하며 일부 동일한 뷰티 행동 변화를 보여줌과 동시에, 서로 구별되는 상이한 행동 변화도 보여주었다. 따라서 코로나 19 라 는 상황적 요인을 우선 이해하고, 세부적인 화장품 개발 및 판매 전 략을 수립할 때에는 $\mathrm{M}$ 세대와 $\mathrm{Z}$ 세대의 상이한 뷰티 니즈를 파악하고 차별화된 마케팅 전략을 강화할 필요가 있다. 예를 들어 코로나 상황 에서 생겨난 뷰티 고민을 위한 화장품 라인을 기획할 때, 그 안의 세 부적인 타겟층을 구분해 제품라인을 구성하는 면밀한 전략이 요구된 다.

본 연구는 코로나19 상황에서 $\mathrm{MZ}$ 세대 소비자의 외모관리행동에 대해 질적연구방법론을 적용하여 보다 심층적이고 면밀하게 파악했 다는 점에서 차별점이 있다. 이와 같은 주요한 연구 결과를 토대로 코로나 19 상황에서 $\mathrm{MZ}$ 소비자의 근본적인 고민을 해소시켜줄 수 있 는 화장품과 관련 서비스를 개발할 필요가 있다. 향후 본 연구의 외 모관리행동 패러다임 모형을 활용하여 소비자의 상황을 맥락적으로 파악하여, 향후 기업 마케팅과 제품 개발에 효과적으로 활용될 수 있 기를 기대한다.

\section{Author's contribution}

JSL, BRJ, BRK, and JYL designed the overall study. And JSL, BRJ, and BRK write the paper together. All authors read and confirmed the final version of the paper.

\section{Author details}

Je-Sung Lee (Graduate Student), Department of Economics and Finance, Sangmyung University, 20 Hongjimun 2-gil, Jongno-gu, Seoul 03016, Korea; Boram Jun (Researcher), COSMAX R\&I Center, 255, Pangyo-ro, Bundang-gu, Seongnam-si, Gyeonggi-do, 13486, Korea; Byeo-Ree Kim (Researcher), COSMAX R\&I Center, 255, Pangyo-ro, Bundang-gu, Seongnam-si, Gyeonggi-do, 13486, Korea; June-Young Lee (Professor), Department of Economics and Finance, Sangmyung University, 20 Hongjimun 2-gil, Jongno-gu, Seoul 03016, Korea.

\section{References}

Hong ST, Park EA. Comparison of female consumers' purchasing behavior by lifestyle types: in the case of cosmetics. Korean Journal of Marketing, 20: 55-89, 2005.

Jun SH, Kim JH. Theoretical background and prospects for the untact industry. Journal of New Industry and Business, 38: 96-116, 2020.

Koo HG, Rha JY. A study to explore female consumer's cosmetics using context by observation and in-depth interview approaches. Journal of Consumption Culture, 18: 147-179, 2015.

Lee HS, Kim JH. Analysis of food consumption behavior due to COVID-19: focusing on MZ generation. Journal of Digital Convergence, 19: 47-54, 2021.

Oh YJ. Influence of a cosmetic company's eco-friendly activities on consumers' purchase intention through the mediating effects of perceived image. Asian Journal of Beauty and Cosmetology, 18: 149-161, 2020a.

Oh YK. Effects of cosmetics purchase decision factors of female university students in Korea and Taiwan on the Korea cosmetics satisfaction. Asian Journal of Beauty and Cosmetology, 18: 619-628, 2020b.

Park HJ. The new cosmetics trend research in the new normal era through big data analysis. Korean Society of cosmetics and Cosmetology, 10: 465-480, 2020. 
Park YM, Kim HY. A study on changes in women's makeup Interest and use patterns before and after the outbreak of COVID-19. Asian Journal of Beauty and Cosmetology, 19: 129-138, 2021.

Seo JH. Govermnance of urban regeneration platform and goldilocks'dilemma. The Korean Governance Review, 27: 1-28, 2020.
Sun SH. A study on expanding consumer receptivity to the result of product development through FGI (focus group interview). Journal of Industrial Design Studies, 8: 19-26, 2014.

Yeo JS, Jun SM, Kim SY. Consumer research: quantitative methods and qualitative methods. Gyomoonsa, Paju-si, pp58-62, 2012. 


\section{국문초록}

\section{포스트 코로나 시대의 MZ세대의 외모관리행동 분석}

이제성 ${ }^{1}$ 전보람 ${ }^{2}$, 김벼리 ${ }^{2}$, 이준영 ${ }^{3 *}$

${ }^{1}$ 상명대학교 글로벌생활환경학과 소비자학 전공, 서울, 한국

${ }^{2}$ 코스맥스 글로벌R\&I, 경기도 성남시, 한국

${ }^{3}$ 상명대학교 금융경제학부, 서울, 한국

목적: 본 연구는 MZ세대를 중심으로 코로나 발생 이후 변화한 외모관리행동에 대해 분석하였다. 이를 살펴보기 위해 코로나 확산 이후 MZ세대의 뷰티 행동 패러다임 모형을 설계하고, 세부적인 뷰티 행동에 대해 살펴보는 것에 연구 목적을 두었다. 방법: MZ소 비자들의 코로나 발생 이후 변화한 행동과 심리에 대해 심층적으로 살펴보기 위해 정성 연구 기법 중 심층 인터뷰를 활용하였다. 결 과: $\mathrm{MZ}$ 세대는 코로나와 같은 상황적 요인에 따라 생겨나는 뷰티 고민을 해결하기 위해 화장품을 소비하고, 화장품 사용과 더불어 행해지는 외모관리행동을 뷰티 루틴으로 정착시키고, 이를 통해 개인의 이상적 모습을 표현하는 것으로 나타났다. 코로나 이후 $\mathrm{MZ}$ 세대는 이전과 다른 상황 속에서 다양한 뷰티 고민이 생겨났다. 이런 고민을 해결하기 위해 기초 케어에 집중하고 뷰티 루틴을 간소 화하는 등의 변화가 이루어졌다. 또한 코로나 종식 이후에는 코로나 전후를 고려한 적정한 수준의 외모관리행동을 계획하는 것으로 도출되었다. 결론: 코로나 이후 MZ세대의 외모관리행동은 상당부분 변화한 것으로 나타났다. 바이러스 확산 이후 변화한 상황 속 에서 새로운 뷰티 고민이 생겨나게 되면서, 세부적인 행동과 심리가 달라졌다. 따라서 코로나 상황 속에서 MZ세대의 니즈를 만족시 키기 위한 화장품 개발 및 마케팅 전략이 새롭게 계획되어야 할 필요가 있다.

핵심어: $\mathrm{MZ}$ 세대, 외모관리행동, 포스트 코로나, 소비자 행동, 소비자 심리

\section{참고문헌}

강구혜경, 나종연. 여성 소비자의 화장행동 분석을 통한 화장 맥락의 이해. 소비문화연구, $18: 147-179,2015$.

박윤미, 김휘율, 코로나 19 (COVID-19) 발생 이전·이후의 여성 화장 관심도 및 화장품 사용실태 변화 분석. 아시안뷰티화

장품학술지, 19: 129-138, 2021.

박혜진. 뉴 노멀 시대의 빅 데이터 분석을 통한 화장품 트렌드에 대한 연구. 한국화장품미용학회지, 10: 465-480, 2020.

서정훈. 도시재생 플랫폼의 거버넌스의 골디락스의 난제: 도시재생 뉴딜사업 사례분석. 한국거버넌스학회보, 27: 1-28, 2020.

선섭희. FGI(Focus Group Interview)를 통한 제품개발의 소비자 수용도 확대방안 연구. 산업디자인학연구, 8: 19-26, 2014

여정성, 전상민, 김소연. 소비자 연구방법: 정량적 분석과 정성적 분석. 교문사, 파주, $\mathrm{pp} 58-62,2012$.

오유진. 화장품 기업의 친환경활동이 지각된 이미지를 매개로 화장품 구매의도에 미치는 영향. 아시안뷰티화장품학술지, 18: $149-161,2020 \mathrm{a}$

오윤경. 한국과 대만 여대생의 화장품 구매결정요인이 한국화장품의 만족도에 미치는 영향. 아시안뷰티화장품학술지, 18 : $619-628,2020 \mathrm{~b}$

이홍승, 김준환, 코로나19로 인한 식품 소비행태 변화 분석: MZ세대를 중심으로. 디지털융복합연구, 19: 47-54, 2021. 전승화, 김정호, 언택트(Untact) 산업 확산의 이론적 배경과 전망. 신산업경영저널, 38: 96-116, 2020.

홍성태, 박은아, 라이프스타일 유형별 여성 소비자의 구매행태 비교: 화장품 구매를 중심으로. 마케팅연구, 20: 55-89, 2005. 


\section{中文摘要}

\section{后新型冠状时代MZ一代外观管理行为分析}

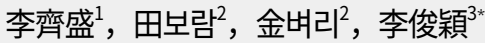

1 祥明大学全球生活环境系消费者研究系，首尔，韩国

${ }^{2}$ Cosmax全球 R\&l, 京畿道城南市, 韩国

祥明大学金融经济学科, 首尔, 韩国

目的: 本研究的重点探讨MZ 一代在COVID-19 爆发后外观管理行为的变化。目的是为 COVID-19 传播后 MZ 代的美容行为设计一个范式模型，观察其美容行为。方法: 使用定性研究技术中的深度访谈来检查 COVID-19 爆 发后 $M Z$ 一代的深度行为和心理变化。结果: $M Z$ 一代消费化妆品并设定外观管理行为, 同时将化妆品用作美容 程序，以解决因情境因素（例如COVID-19）引起的美容问题, 从而表达个人的理想外观。在 COVID-19 之后, $M Z$ 一代有了与疫情爆发前不同的各种美容问题。为了解决这些问题, MZ 一代做出了改变, 比如专注于护肤和 简化美容程序。在 COVID-19 结束后, 考虑到 COVID-19 前后的时代, MZ 一代正在规划适当水平的外观管理行 为。结论: 自 COVID-19 爆发以来, $M Z$ 一代的外观管理行为发生了显着变化。随着病毒传播后出现了新的美容 问题, 详细的行为心理学发生了变化。因此，有必要制定新的化妆品开发和营销策略，以满足大流行期间MZ一 代的需求。

关键词: $M Z$ 一代，外观管理行为，电晕后，消费者行为，消费者心理 
